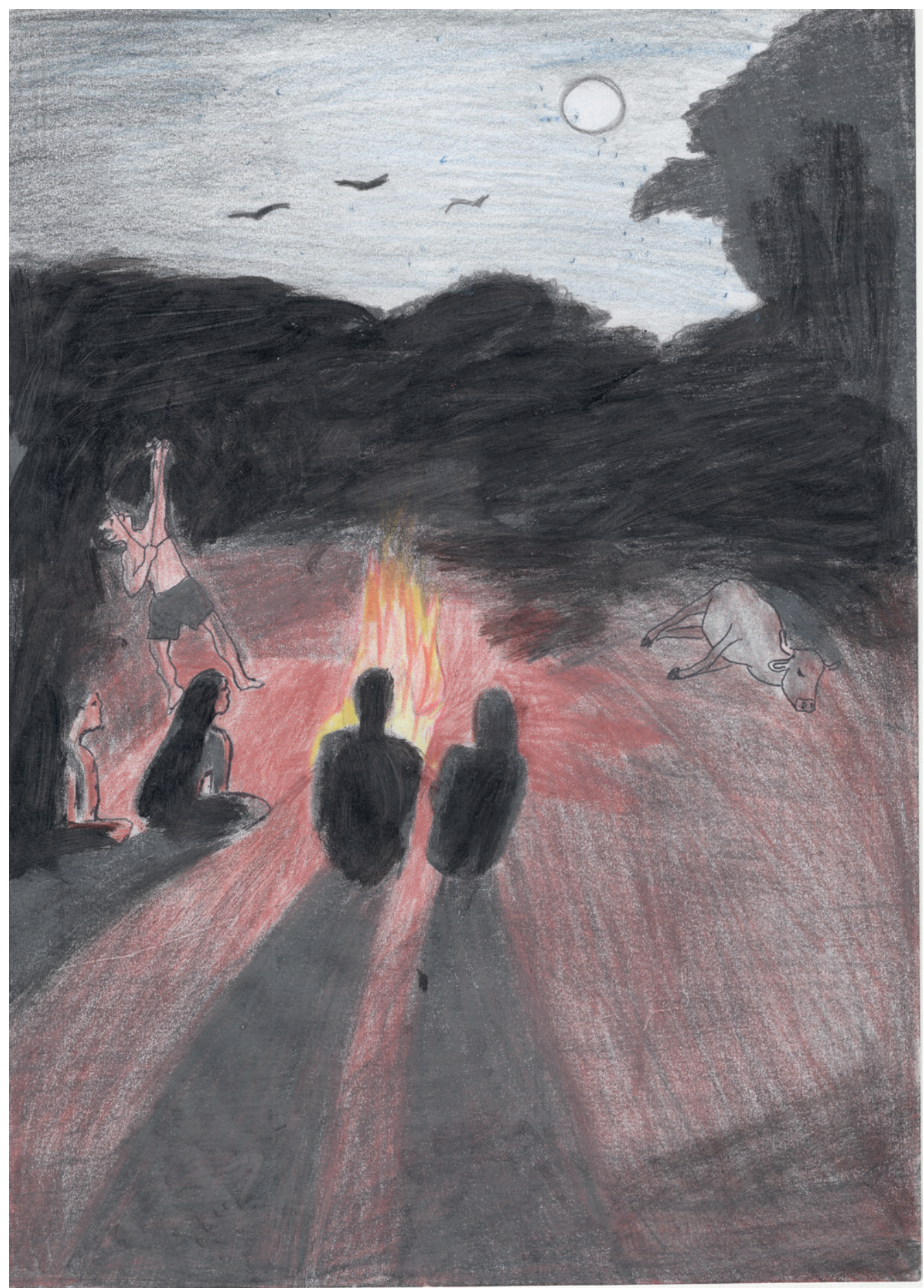




\section{Yatxtxo Khiahe}

Teresa Maria do Espírito Santo

I kkasey he Yaathelha ke i saathathise. Nema itookhethanelha saathathilhaka de. Kdonehlefa ta i kejnika nedeka de Yaathelha ke. Nema itkha ketite txhualhama, i sakhotle ewlinkyase, i satkhalaykya txkyasede. Nema i sesa etho klilane fliawa sato ke i txhatnelhaka de Yaathelha saathethite.

Nema uunima i nankya teka de tha ktshalenelhankena Yaathelha tha sakfalse ke khankya. Nedelhakahe ya thohiawa ya holhaka. Nema txhua Yaathelhama sate siineho ta mukãwa futxilhalhaka de ta ktshalenelha ksa edosey ke. Ama ekhde? Nema uunima i nankya teka de otxhaytowalha ktshale ke tha sa tesiinelhaka fatay ke. Senenkya de tediaka teka de nedekke. Txhua Yaathelhama yasasato esi. Nema Yaathelhanama txhua sakfalse laiman senenkya de tediase lwa teekahe kaske.

Ikkalhawma i unide khia dohe oso lhawa ke dutine, ama ekhde? I takelha sato khia lwahe edwa. Otxhaytowalha eti txhua fliwawa sato holhaka. Nema nesolha sato eti de txhua setkenelha sato ekhdowahe. Efekhlawa theetxondowa khia tha itilhaka de i ekhelhate. Uunima i neskawdotkya hle. Tonkya tatha? Txhua thake senenkyalhadema sayti lhawa itxo, ama ekhde? Ioslalhawa eflidwane. Nema i ta kukilhaka nante i holhawka de.

I senenkyalha elka khla nankyase hle. Nehlefa i kakalha khla i nanse, i nankya khlase hle lahele. Nema uunima senenkyalha kaka ya nankya xkya, kdonehlefa yasa txtxo khdedeka teka, senenkyalha kaka etxdjowasewde. Yoo wati etsha tulkyate, ama ekhde? Sa satantaksena sandotka ke seho. Sate yatkha ke nantena ewtakdoalha sato khlaktekke hle.

Nema txhana sokhlokodonkyalha, oote tetxdjonkyalha sato, yake fekhlatwa holhaka de sake xinitey i kexalha so toonawa saekhlete. Ya toonawa, tha txhua toonawa te tha saekhleka takanema, txhua edutiwa sato ke tha koxte khia. Nema nehode, nehodeke, unilhaka dehe, ama ekhde? Nema i nelhaskawdotkya hle de. Nehodeke i tha yoonelhaka teka de. Otxhaytowalha fthadwa yeenide hle, yeenide. Nefa ya tutxhialha sdey, ya txtxo lhawa sasnidwate, yake ewte khialha satkwa de. Otxhaytowalha fniho dwa txhua se tutxhialha khotsha sdey sakhoho tshasnite eynika makdowa. I txtxo khiaka edalha sato. Nema nekdey yasa Ta yoonelhaka dehe. Nelha kte yasa setilxinete. 
Woo sato i sesa, wa yaadedwandwa sato, sa tkhalaykya note Yaathelhamaka, wa satkhalayte. Neskedina Ta khukhilhaka ekhdene. Neho denkya kese sekhotlese mak'ho.

\section{Nedekteka.}

Nekdey otxhaytowalha ktshaletena tha ktshalenelha satkwate. Owa fea txkyalha ke, tha efendowalha da. Nema unika, unika wa sanolnedete, ama ekhde? Wa nektay ke wa txtxolha kakawa sasnidwate, wa maynilhaka nokahe hle de. Ya txtxo khiate, wa txtxondotkya, owalha txhatxletwa sato. Oso lhawa owa txtxo khiate, tha txtxondotkya, ama ekhde? I tookhethanelha sa takelha etsolhakahe i khofean i takehe tetti. Nelhaskawdode hle, ama ekhde? I tha yoonelha satkwa teka de sokhlokodonkyalha lalianelha. I lhawa i txkwa tha yoonelhaka dehe. Nelhaktay i tooke i txtxo khiate. I txhatxletwalha sato i txtxondotkya.

Nema unika de wake xinedwa. Kaske ya holha kane unika, katinga, ya khdehewa fdate, yaakhay fdate. Lefetialha se teekhay edwanelha, luxtutwa kesey ya holhaka. Newke, lefetia fthane, lefetialha fthowa dooka, kahne. Anhan. Yooxto tokhe te fdate.

Nema i kfalse ke khankya isone dwanewa. I sesa ekhlane. Seynedonkya txilhaka de efekhlawa tole, txo Visentin tole, katinga wewa ksa ewte. Nema txhua luxtutwa nose dey theesenelhaka. Nema neho etxhasede tha tximan hle txhua etxnesolha tha kthataxi neho te takte, neho te saakha nete. Nema, neho lwa khia dehe yasa etxhi txhua dododwa sato.

- Neso! Neho! Enhen! Owawa, owawa te.

Ya fnelhalhaka.

I tookhethalha fthowa nekase. I tookhetha wati dodwase i ewlinho fthowa. Nema txhua setsnehe ke nolhaka de elsinete, Yaathe ke i nekahe. May elsinete é jogankya, i nete owa khlaithe. Nolhaka toonawa ta saykhlete. Nema owa txtxayalha txhua ke noxte khia. Theeke sakinte txhua elsnese ke. Txhua otxaxkya eyawa ta futxman etxte khia neho waley, txhua txidjowa, tato teeyni khiaka de. Txhua kitxhia walxakadwawa lay etxte, txhua maltxi walxakadwawa. Nema nehowa lay etxman, isya, itookhethanelha etxte khia neho txhufnite tate phuphunese nete. Txhua tate ta etxondowa awa kfedjo nete. Nema nehodeke... Nehodeke eyalhaka de, may yaosla eflidwa khiaka de. Ya tetialhaka de. Nekdey ya sesa eduti ke, txhua sasa tsa khia, sasatnise khia ke.

- Neho! Neso! Koxi, muyé, a oxi neso ke owa kte nelhaka de.

Nema unima ya nedeka hle ya txtxo khia, mew fiw. Nema nekawde te i kfalse txakhankya dehe. 
Isilha, fliwalha, fliwanelhalhaka. Nema kokhmati lhawa eefelha fthowa nelhaka de owa fowalha ke. Nema nehode neho noxte khia fowa tuy. Neka tempo ke nato nelhaka de txhua engenho te donesaka de ta tetxdjowa khia te hendelu. Nema nehode kixte khia kabasawa ke. Txhua leya nato djwa lay. Nema ya sdey txhua xiklawa djoawa ta koxte khia. Nema txhua phuphunese yeehaxte khia txhua nato, ama ekhde?

Nema nehode te sainte. I sainkya khlakase hle de. I neka khla nankyase, i dokhea khla nanse hle. Ama ekhde?

Nema itkha ewlinhose itookhetha naniho tsea khia de. Toonawa... nekdey e holhaka toonawa te saekhlete. Nema yoo wati ya dokhea wati dose khia de neho wake yankyake. Toonawa de nekdey ewdowa khia. Nekdey etxte, enhen, itookhethanelha ke txilhaka de:

- Findey, i neho te saekhlekase. Unika tetixi. Nema ya neho eytxinene, neso ya eytxinene, nehowa sato yeetxite. - Ta nelhaka.

Nema ta netnelhasatkwa fotxha ke i lhawa txkwa teka de. Ta didilhasato fekhdi nekasewde exnete, ama ekhde?

Nema i wa kfalselha naaneka teka de. Senenkyalha kaka watoawa saykhlelha takanema, nekte neho wati te neho ke kote, may sakmana yasa netkadekahe.

A nahalhaka owa: itkhamti lhawa tole ya txadialhakane awa setsnehelha ke tafolha te txhua kfelnese wake ya holhaka, ama ekhde? Nema i txi newde, i txman txhua ya etxondowawa ya saintxkya hle de txhua yamtitwawa ke.

Txhunika ktoawankya ke Eedjadwalha nandoho. Nema nekke i fman nekawdeke ya txtxo lhawa te Ta hahanelhasatkwa dehe, ya fman senenkya tediase lwa ta etenelhasatkwa. Salhankyake nelhakahe, ama ekhde?

Nekdey thoolhasatkwa teka away, may safmana needefasa. Nema i wakelha neka dede. Wa satkhalhalaykya txtxa makkya. Nema wa txtxolha kaka ti walha Take nexto lha nelhakke takanema wa unikawde, wa txtxolha sasnidwa kakawke, wa txalhaknokahe. Nema wa satxtxolha neka ekhdete, ama ekhde? I fman lhawa i thelha i thefea hle fasa. 


\section{Nossa Vida Era Assim}

Teresa Maria do Espírito Santo

Eu era pequena, já falava Yaathe. Então minha mãe falava Yaathe, mas ela não me ensinou a falar em Yaathe. Era o que eu mais queria: aprender a língua. Eu vivia procurando os que tinham mais conhecimento do que eu da língua. As velhas me ensinaram a falar a língua.

Hoje eu vejo que só se interessam em estudar coisas do branco. Só colocam isso na cabeça. Não era assim quando éramos pequenos. $\mathrm{O}$ índio que valorizar a língua e procurar aprender, ele aprende rápido, sem precisar estudar coisas de não índio, sabe? Eu vejo hoje que se iludem com o discurso dos não índios. Aí fica difícil porque não é certo. O índio que busca mesmo a língua, aquele que busca falar e colocar a nossa língua na cabeça, o que era difícil fica fácil.

Quando eu era pequena, eu não era assim, não, porque eu era muito humilde, sabe? Nem roupa eu tinha! As velhinhas iam na casa dos não índios. Elas pegavam as roupas usadas. As velhas traziam e me davam para eu vestir. Hoje não é como no tempo passado. Hoje ganhamos até presentes. O meu coração é bom. Então eu vivo rezando a Deus.

Eu já vi muitas coisas ruins. Mas também já vi muitas coisas boas. Hoje nós estamos vendo coisas boas, mas a gente não sabe o que é que faz com todas as melhorias. Nós mesmos trabalhamos no meio de muita gente, sabe? Que só anda querendo as coisas. Alguns só pensam na grandeza; anda gente aí querendo ser maior do que o outro.

Aqueles do passado, aqueles que passaram, os velhinhos, andavam em vários lugares para conseguir algo. Quando conseguiam alguma coisa, eles dividiam com os outros necessitados. Eles faziam assim, sabe? Eles não faziam as coisas só para si. Eu agradeço tudo isso que vi dos meus antigos. Nós não somos como os privilegiados. Nós não somos. Porém, estamos melhor agora, graças a Deus. Estamos melhor. Hoje nós não andamos pedindo esmola nas portas, como os outros, para comer. Deus não deixa a gente pedindo emolas. Por tudo isso, nós agradecemos a Deus. E foi por isso que Deus concedeu à gente: para estarmos felizes.

Vocês que são meninos, mais jovens do que eu, têm de se interessar e procurar saber falar sobre o nosso idioma, aí vocês vão saber falar. Porque isso ajuda. 
A gente não é assim.

Toda vez vocês sempre falam a língua dos outros, a língua deles. Mas sabemos que alguns não índios não respeitam esta terra. Então isso é muito ruim para a gente, sabe? Enquanto vocês respeitarem essa terra aqui, vocês terão muita felicidade. Era o jeito dos nosso antigos, mas não é o jeito de vocês agora, dos nossos parentes. Os meus antepassados não eram como eu, entende?

A minha mãe descosturava a roupa dela para eu poder vestir, para fazer roupa para eu vestir. Nós não somos mais assim, sabe? Estamos agradecendo a Deus por esses tempos passados. Estou agradecendo a Deus por estar passando esses dias todos. Enquanto isso, eu não sou mais como era antigamente. Os meus parentes não são como eu era antigamente.

É disso que eu estou falando para vocês. De novo, nós andávamos assim, pela caatinga, caçando o que comer, caçando o de comer. Até os bois mortos no mato nós pegávamos, nós andávamos feito urubu. Então, morria uma vaca, morria uma vaquinha, dizem: sim. Vamos procurar.

Ainda lembro da minha irmã que morreu. Ela era mais velha do que eu. Quando era mocinha, vinha mais um velho, velho Vicente, por dentro do mato. Por onde o urubu ia, a gente ia atrás. Então quando um bicho caía, eles chegavam em cima e levavam para fazer a comida. Até isso nós repartíamos entre aqueles que não iam. Eles diziam tome para uns e para os outros, tome esse.

Nós fazíamos isso.

Eu tive um pai. Não foi meu pai quem me criou. Então ele ia para aquela cidade jogar, jogar, como eu digo em Yaathe. Mas elsinete é jogatina, para eu dizer na fala dos não índios. Ele ia para conseguir uma coisinha. Um dia ele ia de noite. Ele sentava ali. Quando arrumava dinheiro, pouquinho, vinha com aqueles peixes, rabo de boi que ele comprava. Vinha com aquele litrinho de farinha, aquele litrinho de milho. Aí quando ele chegava com aquilo, minha mãe pegava para fazer fubá. Aquela mistura que ele trazia. Então tudo isso... Tudo isso era pouco, mas nosso coração era limpo. A gente tinha pena. A gente sempre dava para as pessoas mais pobres do que a gente, para as pessoas que estavam perto da gente.

- Fulano! Fulana! Vá, mulher, dar um pouquinho de comer naquela dali.

Hoje não somos mais como éramos antes. De tudo isso eu ainda me lembro.

A minha avó era uma velha, uma velhinha. O parceiro dela tinha um sítio lá na serra. Ele ia para a serra. Nesse tempo tinha mel daquele engenho de cana-deaçúcar que o rendeiro dele fazia. E ele tirava em uma cabaça. Aquela cabaça cheia com mel. Aí a cada uma de nós ele dava uma xícara cheia. Com aquele fubá nós comíamos o mel, sabe? 
Nós nos deparávamos com tudo isso. Eu já enfrentei muitas dificuldades. Eu já passei muita coisa, eu já passei muita fome. Sabe? Quem me criou foi meu padrasto. Ele andava muito para conseguir uma coisinha. Aí a gente não passava muita fome por conta do que ele fazia por nós. Ele andava em busca de coisas. Chegava para minha mãe e dizia:

- Finda, olha, eu arrumei isso. E aí nós vamos chamar fulano, nós vamos chamar fulana, nós vamos chamar as pessoas para comer uma coisinha, ele dizia.

Por conta dessas ações dele, eu estou aqui. Contando essas histórias.

Eu estou mostrando para vocês. Quando vocês conseguirem algo bom, sejam solidários e compartilhem com os outros.

Veja isso: eu saía com esse meu camarada, nós andávamos nas cidades, apresentando nossa cultura, entende? E quando ele vinha de lá, quando chegava tudo aquilo que nós trazíamos, nós dividíamos com os nossos amigos.

Tudo isso Deus está vendo. E por isso eu acho que Deus teve compaixão de nós. Deus melhorou o nosso caminho. Por conta de Deus nós contamos essa história, sabe?

Sempre alguns procuram coisas só para si. Então eu digo a vocês que não é assim. Vocês vêm se preocupando para a vida de vocês melhorar. Se vocês orarem muito, vocês conseguirão, fazendo isso, vocês terão uma vida melhor. Vocês vão saber se organizar melhor, sabe?

Para mim, essas são as minhas histórias. 


\section{That was our life}

Teresa Maria do Espírito Santo

I was little, I already spoke Yaathe. My mother spoke Yaathe, but she never taught me to speak Yaathe. It was what I wanted most: to learn the language. I was always looking for those who had more knowledge about the language. The old ladies taught me to speak the language.

Now I understand that most people are only interested in studying white people's things. That's all they want to know. It was not like that when we were little. The indians who values their language and try to learn it, will learn quickly, without the need of studying non-indian things. I know that some of them delude themselves with non-indians discourse. It gets dificcult then because it's not right. That Indian who goes after his or her language, who tries to speak his or her language, top ut it in his or her head will notice that whatever it's difficult will become easier.

When I was little, I was not like that; I was very humble. I had no clothes to wear! The old ladies went to the homes of non-indian people and asked them for second-hand clothes. The old ladies brought second-hand clothes and gave them to me so I had something to wear. Today is not like in the past. Today we win gifts and all! My heart is good. So I keep praying to God.

I've seen many bad things. But I have seen many good things too. Today we see good things, but we do not know what to do with all the improvements. We ourselves are in the middle of a lot of people, you know? Those people just want things for them. Some of them only think of opulence. There are so many people out there who just want to be better than their fellows.

Those of the past, those who have passed, the old men, they struggled a lot to have something. When they had something, they shared it with others in need. They were like that, you know? They didn't keep things only for themselves. I appreciate all that I've learned from my ancestors. We are not like the privileged people. We are not. But we are better now, thank God. We are better. Now we don't have to go around begging on the doors, so we can have something to eat. God does allow us to beg any ore. We thank God for everything. And that's why God has given yhis to us: so we can be happy. 
You who are just boys, much younger than I. You have to be interested and try to speak our language, then you will be able to speak it. Because it helps.

We are not like that.

You always speak the language of others, their language. However, we know that some non-indians do not respect this land. So this is very bad for us, you know? As long as you respect this land here, you will be very happy. This was the way of life of our ancestors, but it's not your way of life now, the way of life of our relatives. My ancestors were not like me, do you understand?

My mother resized her own clothes for me to wear; she used her own clothes to make clothes for me to wear. We are not like that anymore, you know? We thank God for not being like the od days. I thank God because these days are over now. Meanwhile, I am no longer as I was before. My relatives are not like they were before.

That's what I'm talking to you. Again: we walked around the caatinga, hunting for something to eat, hunting for food. We used to get dead cattle; we were like vultures. So if a cow died, if a little cow died, we were like "ok, let's go and find it".

I still remember my sister who died. She was older than me. When I was girl, there was this old man, old Vicente, who came from the bush. Wherever the vultures were, we went there. So when an animal fell dead, they came up and took it to make food. Even that we used to share among those who could not go there. They said: "take this for some of you and that for some others".

That's what we used to do.

I had a father. It was not my father who raised me. Then he went to that city to play, to play, as I say in Yaathe. But "elsinete" is gambling, so I can translate it into the non-indian language. He went there to get a little something. Sometimes he went there in the evening. He sat there. When he got some money, some little money, he returned with fish, oxtail, anything that he bought. He came back with that bottle full of manioc flour, that little bottle full of corn. Then when he came with these things, my mother took the corn to make cornmeal. With that little something that he brought. So that was that. We didn't have a loto $f$ things, but our heart was clean. We pitied the unfortunate ones. We always gave things to people who were poorer than us, to the people who were close to us.

- John Doe! Jane Doe! Go, woman, give a little something to those people, so they can have what to eat.

Today we are no longer as we were before. I still remember all these things.

My grandmother was an old, old lady. Her partner had a place there in the mountains. He went to the mountains. At that time, there was honey from that 
sugarcane mill that the worker over there used to make. And he collected it in a gourd. That gourd filled with honey. Then he gave a full cup of honey to each of us. We then ate honey with that corn meal, you know?

We used to experience all these things. I have faced many difficulties. I've been through a lot, I've experienced hunger, you know? I was raised by my stepfather. He did a lot of things to get a little something. So we did't get hungry because of what he did for us. He was Always looking for something. He used to say to my mother:

- Finda, look, I found this. We are going to invite John Doe, Jane Doe, are going to invite everyone to eat a little something - he said.

Because of these actions, I'm here. Telling these stories.

I'm telling you. When you get something good, be helpful and to share it with other people.

Consider this: I used to go out with this buddy of mine, we went to the big cities to present our culture, you know? And when he arrived from there, when we arrived with all the things that we got there, we shared everything with our friends.

God is watching us. That's why I think God had mercy on us. God has improved our life. It's because of God that we tell this story, you know?

There's Always someone looking for some things just for himself. So I say to you that it should not be like this. You worry to have a better life. If you pray a lot, you'll succeed. If you do so, you will have a better life. You will learn how to get organized, you know?

These are my stories. 